УДК: $355.23(477): 378.5$

Дмитро Анатолійович Чопа (кандидат технічних наук, с.н.с.) ${ }^{1}$

Анатолій Йосипович Дерев'янчук (кандидат технічних наук, професор) ${ }^{2}$ Владислав Валерійович Дегтярьов 2

${ }^{1}$ Національний університет оборони Украӥни імені Івана Черняховського, Київ, Украӥна

${ }^{2}$ Сумський державний університет, Суми, Украӥна

\title{
ІНФОРМАЦІЙНІ ТЕХНОЛОГІЇ ЯК ТЕХНІЧНА ОСНОВА РОЗВИТКУ СУЧАСНИХ МЕТОДІВ ВИКЛАДАННЯ ВІЙСЬКОВО-ТЕХНІЧНИХ дИСциплІн
}

\begin{abstract}
Сучасні умови застосування Збройних Сил України визначають нові вимоги до організачії навчання та підготовки військових фахівців. Існує нагальна потреба в розробленні нових технологій навчання, підвищенні рівня засвоювання навчального матеріалу та удосконаленні способів контролю його засвоєння. Тому в статті на основі досвіду кафедри військової підготовки Сумського державного університету наводяться основні інновачійні напрями застосування інформаційних технологій у підготовизі військових фахівців (на прикладі спеціалістів РB i A), а саме, створення мультимедійних навчальних комплексів за артилерійською тематикою, створення комп ютерних навчальних систем, впровадження інформаційних і кейс - технологій у систему підготовки військових фахівців, розроблення мультимедійних віртуальних тренажерів (симуляторів), моделювання навчальних ігор, розроблення системи автоматизованої оцінки знань та розроблення інформачійно-дистанційно-тренажерної системи навчання. Автори започатковують власний підхід щзодо концепції застосування сучасних методів викладання військово-технічних дисциилін з метою подальшого їх обговорення, розвитку та впровадження в освітній процес ВВНЗ. В даній статті розглянуто лише частина основних інноваційних напрямів застосування інформаційних технологій. Решта напрямів буде проаналізовано та представлено в наступних публікаціях.

Ключові слова: інформаційні технології; мультимедійні артилерійські комплекси; кейс-метод; комп'ютерні навчальні системи; концепиії.
\end{abstract}

\section{Вступ}

Збройні Сили України (ЗСУ) пройшли випробовування на міцність в умовах боротьби 3 зовнішньою загрозою, підтвердили свою боєздатність. Проте застаріле озброєння і військова техніка (ОВТ), відсутність практичних навичок, слабкі знання особовим складом ОВТ, недосконалість обладнання ремонтних органів, а іноді i їх відсутність, недостатня навчальноматеріальна база, неспроможність орієнтуватися у екстремальних ситуаціях, розгубленість при прийнятті правильних рішень особовим складом призвели до великих втрат людських i матеріально-технічних ресурсів в ході бойових дій. Названі чинники є “ахіллесовою п'ятою” ЗСУ, які потребують не тільки новітнього ОВТ, а й пошуку та застосування новітніх технологій навчання. Безпосередня підготовка бойових дій, як показав досвід військового конфлікту, проводився, зазвичай, в короткі терміни i в скороченому обсязі. Військові підрозділи у своєму складі мали в основному неосвічених і ненавчених воїнів. Для ïx якісного навчання традиційними методами потрібний тривалий період i відповідна матеріально-технічна база.

Постановка проблеми. Зараз існує нагальна потреба у вирішенні дуже складної проблеми: як здійснити якісну підготовку військових спеціалістів за короткий термін навчання (в умовах особливого періоду) та опанування зразками ОВТ, що стоять на озброєнні ЗСУ або швидко поновити отримані раніше і втрачені знання та практичні навички мобілізованими воїнами, для ефективного виконання завдань у зоні проведення ООС (АТО).

У контексті викладеного, заходи щодо підвищення якості навчання 3 точки зору удосконалення практичних навичок, вміння швидко i правильно оцінювати обстановку i приймати правильні рішення потребують інноваційних підходів до системи підготовки відповідних фахівців.

Як показує досвід, знання та практичні навики, що отримані упродовж навчання, 3 часом зменшуються, втрачають свою цінність. Після мобілізації військові потребують певного часу для відновлення знань і вмінь. Таке пояснюється тим, що під час навчання вони не отримали досвіду самостійного опрацювання проблеми, що виникла, пошуку причин та шляхів щодо їі вирішення.

При цьому, відслідковується недостатня орієнтація ВВНЗ на формування у слухачів якостей, що наведені вище, а це позначається на 
якості підготовки спеціалістів.

Мета статті полягає у пошуку, розробленні та ефективному впровадженні стратегічних перспективних інноваційних технологій, рішень i підходів в освітній процес підготовки фахівців.

\section{Виклад основного матеріалу}

\section{дослідження}

Основним завданням, яке стоїть в рамках досліджень щодо впровадження новітніх технологій викладання військово-технічних дисциплін (ВТД), є аналіз сучасних напрацювань у сфері інноваційних методів і технологій, підготовка рекомендацій щодо вибору раціональних варіантів в умовах обмеженого часу на підготовку, виходячи із максимальної ефективності підготовки фахівців. Таке завдання може вирішуватись на основі порівняння та оцінки різних методів і прийомів новітніх способів викладання, що починають застосовуватись у ВBН3.

Для зручності викладу матеріалу, оцінки ефективності i порівняння різних варіантів (напрямів) у викладанні ВТД пропонується низка, на наш погляд, ефективних методик, які можна застосовувати не тільки у ВВН3, а й безпосередньо у військових підрозділах або навчальних центрах.

Осмислення проблем сьогодення у військовій освіті через призму розроблення та розвитку інноваційних технологій, їх впровадження за досвідом кафедри військової підготовки Сумського державного університету, на погляд авторів статті, має суттєве значення як для теорії, так і для практики формування компетентностей військових фахівців.

Погляди авторів, що викладені в цій статті, звичайно, не можуть претендувати на абсолютне обіймання всіх питань підготовки фахівців або безспірність запропонованих рішень. За мету ставилось - привернути увагу до проблеми, шукати і знайти підходи та напрями її вирішення.

На наш погляд, підвищення ефективності викладання ВТД можна забезпечити шляхом реалізації наступних інноваційних напрямів: створення мультимедійних навчальних комплексів за артилерійською тематикою; створення комп'ютерних навчальних систем; впровадження інформаційних і кейс - технологій у систему підготовки військових фахівців; розроблення мультимедійних віртуальних тренажерів (симуляторів); моделювання навчальних ігор; розроблення системи автоматизованої оцінки знань; розроблення інформаційно-дистанційнотренажерної системи навчання.

Враховуючи мету роботи і обсяг матеріалу, у цій статті обмежимося розглядом трьох інноваційних напрямів.

Інновачійний напрям 1. Створення мультимедійних навчальних комплексів за артилерійською тематикою.

Напрям визначає використання технологій, які спрямовані на якісне засвоєння будови та експлуатації ОВТ із застосуванням 3D моделей зразків ОВТ. Розроблення комп'ютерної 3D моделі складається з декількох етапів, які представлені на рис. $1[1]$.

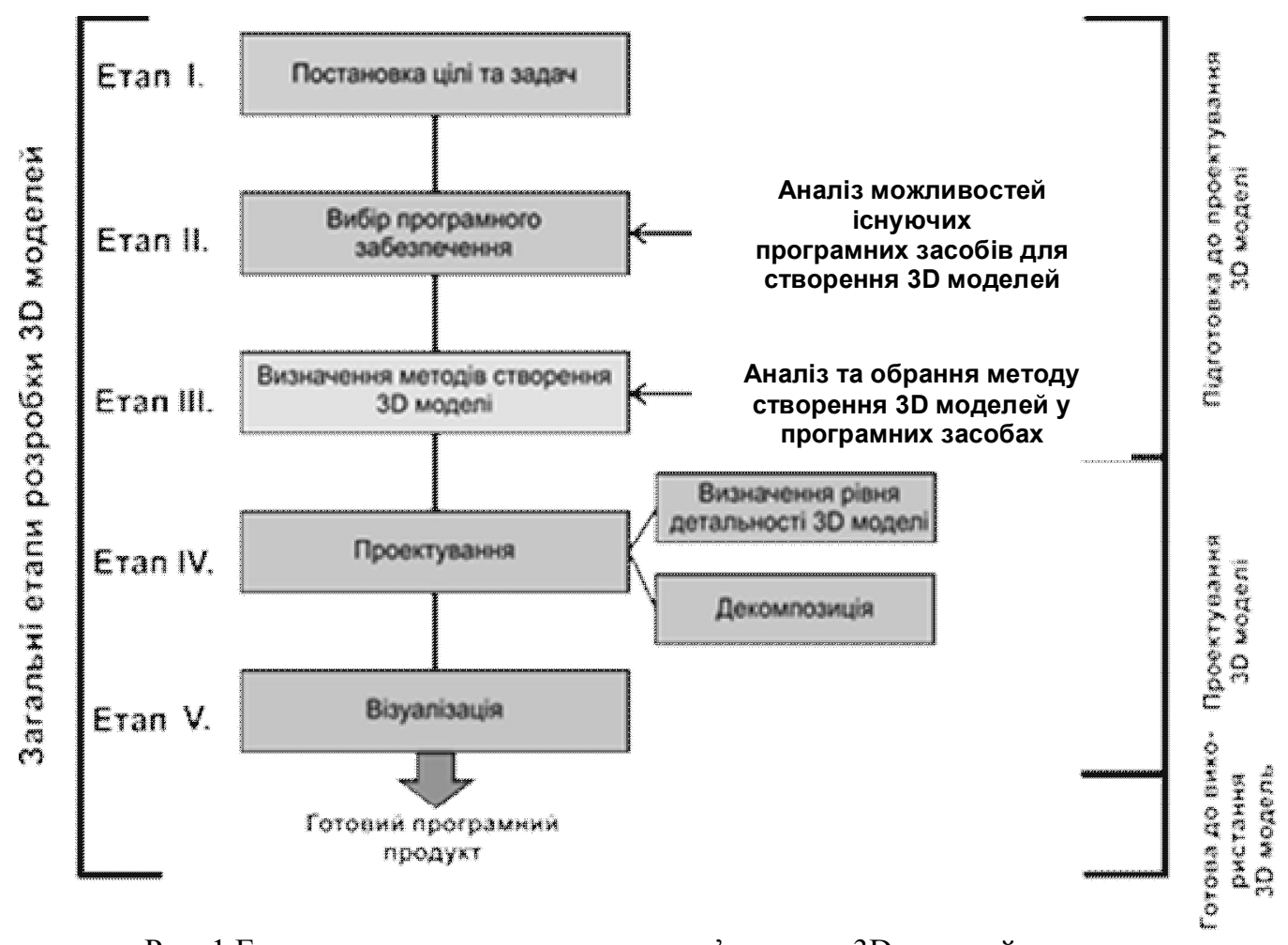

Рис. 1 Етапи створення навчальних комп'ютерних 3D моделей військово-технічного призначення

Створений комплекс має загальну програмну оболонку, до якої підключені окремі структурні частини (рис. 2), що мають вигляд анімаційних відеороликів.

Зміст розробленого електронного засобу навчального призначення (ЕЗНП) дозволяє 
послідовно спостерігати і вивчати будову, дію механізмів та боєприпасів.

Розроблені ЕЗНП відповідають всім нормам і вимогам, щодо створення подібних електронних навчальних матеріалів.

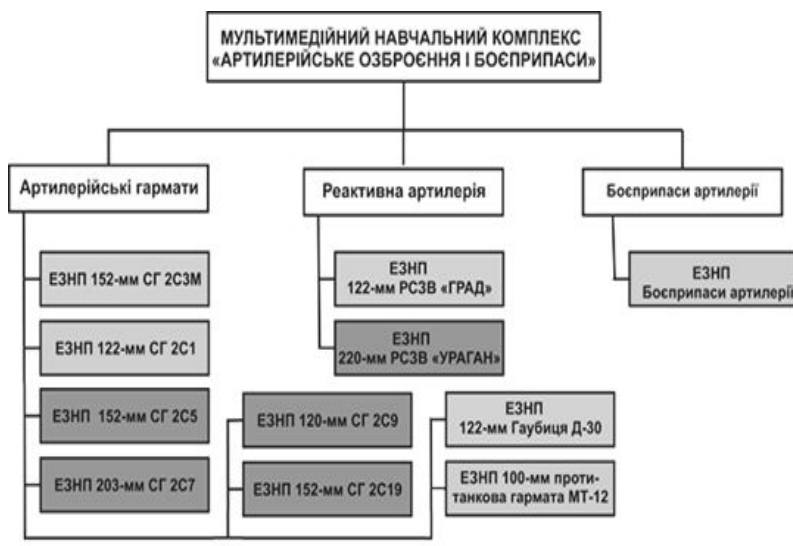

Рис. 2 Схема мультимедійного навчального артилерійського комплексу “Артилерійське озброєння і боєприпаси”

Інноваційний напрям 2. Створення комп'ютерних навчальних систем.

Напрям визначає створення комп'ютерних навчальних систем (КНС) [2-6]. Такі системи часто мають назву комп'ютерні тренажери, тренажери-імітатори, симулятори (англ. Multimedia training system).

Розглянувши низку КНС, автори зупинилися на КНС, що мають наступні переваги: більш глибоке i самостійне вивчення навчального матеріалу; інтерактивна взаємодія користувача 3 контентом; матеріал для вивчення подається у вигляді малюнків, відео фрагментів, таблиць, фотографій тощо; перевірка рівня знань, умінь, навиків користувача в процесі навчання. Використання КНС автори пропонують застосовувати наступним чином.

Підготовка фахівців здійснюється шляхом вивчення нормативних документів, цілей і обсягу завдань технічного обслуговування, конструкторсько-технологічної документації озброєння, вивчення будови зразка озброєння, його окремих вузлів з використанням 3D анімації.

Практична частина дозволяє оцінити знання користувача (фахівця) у вигляді: тестування; виконання робіт з розбирання (складання) 3D моделі; вибір необхідного інструменту і вміння його застосовувати.

Аналіз викладеного вище показав, що, перш за все, необхідно сформувати цілі та задачі, зібрати потрібний матеріал і на основі цього сформувати етапи виконання робіт щодо створення КСН.

Для подальшого дослідження роботи КСН необхідно розробити загальну схему ії створення. Це дозволить у майбутньому додавати блоки у схему при прийнятті на озброєння нових зразків OBT (рис.2). Запропонована авторами схема побудови КСН та методика іiі використання із застосуванням 3D моделі апробована та відпрацьована методом під час створення власних 3D моделей OBT (рис.3).
При створенні КНС необхідно дотримуватись наступних вимог.

Оформлення окремих сторінок екрану повинно характеризуватися інтуїтивно зрозумілим інтерфейсом за рахунок застосування графіки, кольору тощо: вона повинна мати великий запас різноманітних мотивуючих i iнформаційних повідомлень; фахівець (користувач) може активно впливати на процес навчання (зменшувати або збільшувати обсяг матеріалу, вихід на додаткові вправи, тести, літературу тощо); система повинна мати можливість в будь-який момент часу зупинитись 3 збереженням досягнутих до цього часу результатів навчання i забезпечити можливість продовження занять.

Інноваційний напрям 3. Впровадження інформаційних і кейс-технологій у систему підготовки військових фахівців.

Напрям визначає створення i застосування кейс-методу (case-study) - технології навчання, що використовує реальні військово-технічні, військово-тактичні, психологічні, військовомедичні і інші ситуації [7].

Кейс являє собою опис конкретної реальної військово-технічної ситуації, і завданням кейсу $\epsilon$ пошук можливих варіантів ії вирішення.

Основною метою підготовки фахівців під час вивчення ВТД $\epsilon$ формування компетентностей майбутнього офіцера, які будуть їм потрібні під час виконання обов'язків за посадою.

На наш погляд, найбільшого ефекту можна досягти при розумному поєднанні як традиційних, так й інноваційних технологій навчання (використання 3D моделювання, анімаційних відео роликів, віртуальних тренажерів, тестів, тощо), коли вони доповнюють один одного.

Відмінною особливістю кейс-методу $\epsilon$ створення проблемної ситуації на основі фактів 3 реальної військової обстановки (марш артилерійських підрозділів, бойові стрільби, ремонт ОВТ тощо).

Систематичне застосування кейс-методу допомагає студентам миттєво i правильно оцінювати обстановку і приймати рішення, крім того, вони відчувають своє “Я” - я знаю, я вмію, я можу.

На жаль, рамки статті не дозволяють повністю розглянути всі аспекти використання кейстехнологій, тому зупинимося на основних проблемах, які в певній мірі розкривають сутність кейс-метода і методику його застосування.

Зауважимо, що кейс-технологія призначена для розвитку у студентів уміння самостійно приймати рішення i знаходити правильні відповіді на питання.

Відмінною особливістю кейс-методу $\epsilon$ створення проблемної ситуації на основі фактів 3 реальної військової обстановки (марш артилерійських підрозділів, бойові стрільби, ремонт ОВТ тощо).

Систематичне застосування кейс-методу допомагає студентам миттєво i правильно оцінювати обстановку і приймати рішення, крім того, вони відчувають своє “Я” - я знаю, я вмію, я можу. 
На жаль, рамки статті не дозволяють повністю розглянути всі аспекти використання кейстехнологій, тому зупинимося на основних проблемах, які в певній мірі розкривають сутність кейс-метода і методику його застосування.

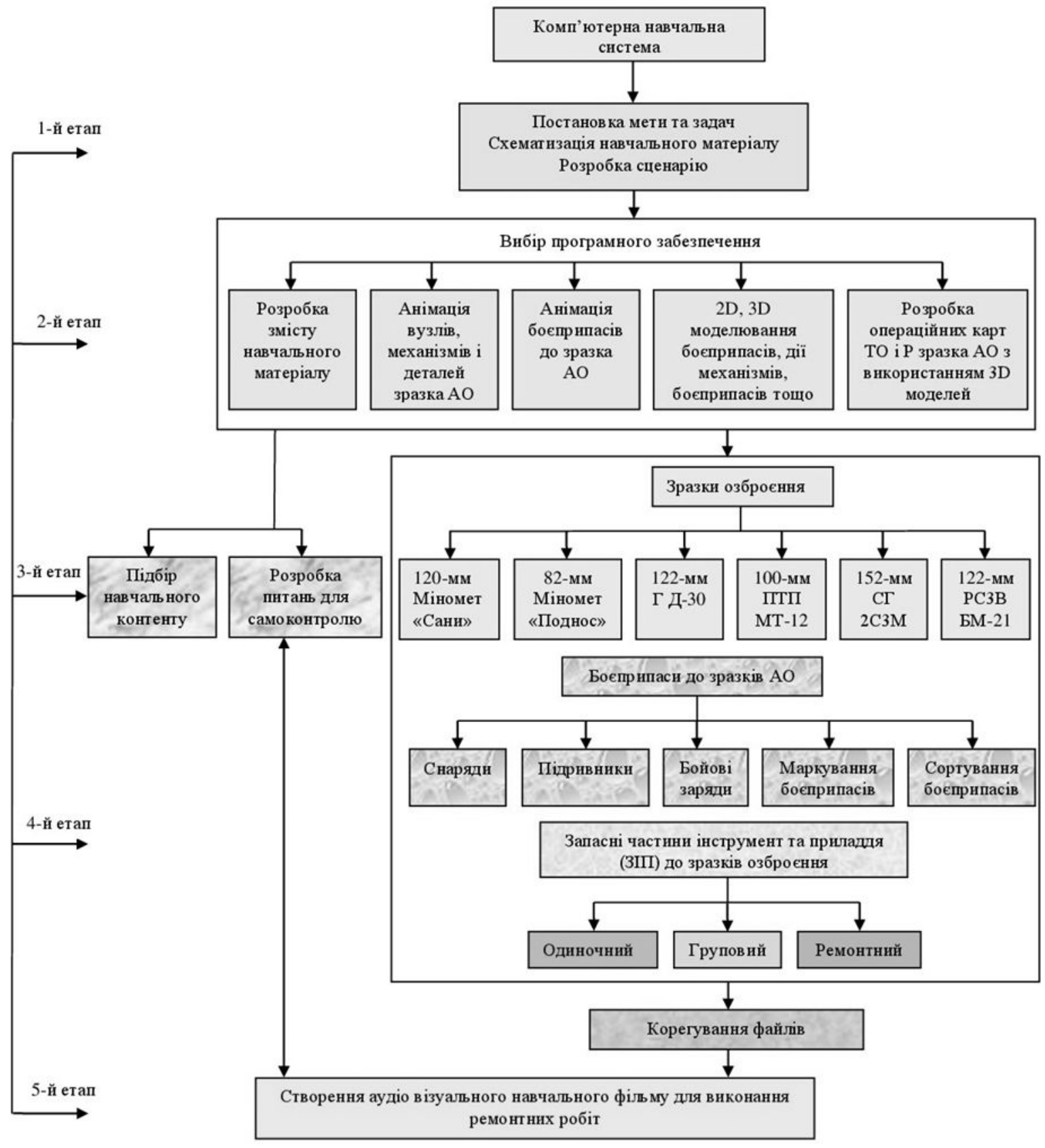

Рис. 3 Загальна схема побудови КСН та етапи іiї створення

Зауважимо, що кейс-технологія призначена для розвитку у студентів уміння самостійно приймати рішення i знаходити правильні відповіді на питання.

Почнемо 3 того, що студентам пропонують осмислити реальну військово-технічну ситуацію, опис якої відображає не тільки якусь практичну проблему, але й актуалізує певний комплекс знань, який необхідно засвоїти для вирішення даної проблеми.

Розглянемо послідовність побудови кейса, або, як прийнято, етапи побудови, від змісту яких буде залежати успіх застосування кейсу.

В першу чергу, необхідно сформувати дидактичну мету кейсу. Потім визначити проблемну ситуацію (визначити конкретний випадок).

3 викладеного вище будемо розуміти наступне: якісний кейс розповідає та фокусується на темі, не виходить за межі програми, кейс містить відео ролики, фрагменти відео фільмів, таблиці, діаграми, графіки тощо, а також проблеми, що зрозумілі студентам.

Досвід показує, якщо тема об'ємна, то доцільно розробляти декілька кейсів і надавати можливість студентам самостійно обирати кейс (рис.4).

B інших кейсах може бути тематика 3 боєприпасів, будови гармат, бойового застосування гармати тощо. 
На інтерактивній дошці виставляються три кейси (рис. 4). При наведенні курсору миші на конкретний кейс, він відкривається і з'являється тематика кейсу (рис. 4, в). Через декілька секунд із кейсу “випливає” проблема (конкретна ситуація), яку студенти повинні вирішити.
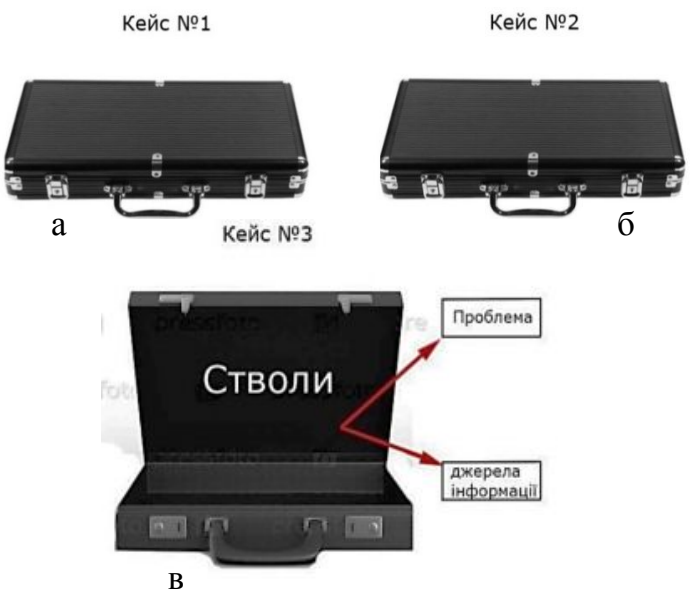

Рис. 4 Набір кейсів: а,б - замкнуті кейси; в - обраний кейс.

Після ознайомлення із завданням, із кейсу “випливає” перелік джерел інформації згідно теми проблеми (ситуації) (рис. 4 в).

3 метою удосконалення створення кейсів та методики їх застосування серед студентів проводилось опитування щодо оцінки кейсу.

Результати опитування відображені на рис. 5.

\section{Jimepamypa}

1.Колганова A.I. Метод case-study как современная педагогических технология в образовании взрослых URL: http://www.docplayer.ru/31560686-Metod-case-study -kak-sovremennaya-anii-vzroslyh-kolganova-alla-ivanovnazav-sektorom-gcrdo.html. 2. Величко Г.Г. Комп'ютерні технології навчання. Сучасні інформаційні технології та інноваційні методики навчання в підготовці фахівців: методологія, теорія, досвід, проблеми. Зб. наук. пр. У 2х част. Ч.2. / За ред. І.А. Зязюна (голова) та ін. Київ.Вінниця: ДОВ Вінниця, 2002. 531 с. С. 17-21. 3. Дерев'янчук А.Й, Чопа Д.А. Підхід до створення програмних засобів для вивчення військово-технічних дисциплін. Сучасні інформаційні технології в сфері безпеки та оборони. НУОУ. 2012. №1(13). 4. Дерев'янчук А.Й., Москаленко Д.Р., Дьяков А.В. Використання інформаційних технологій при вивченні

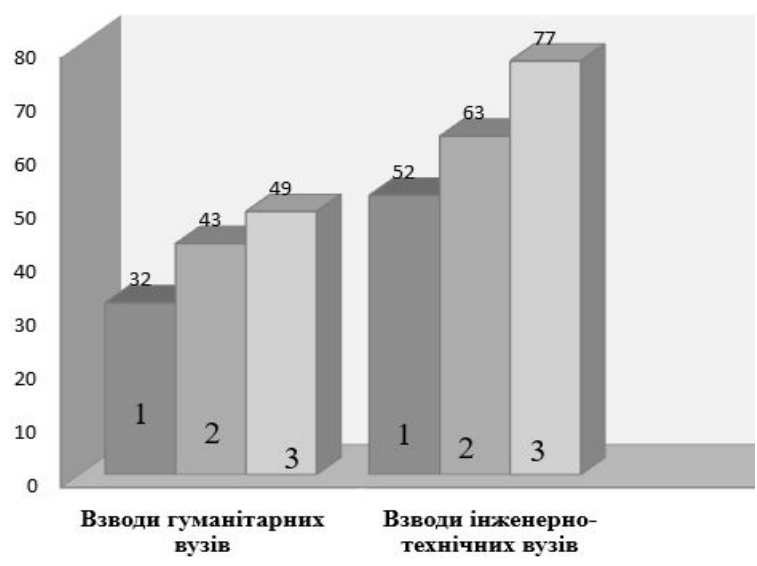

Рис. 5 Рівень оцінювання знань кейс-методом студентами: 1, 2, 3 - умовне позначення навчального взводу

\section{Висновки і перспективи подальших досліджень}

Таким чином, дуже стисло розглянуті окремі інноваційні напрями застосування інформаційних технологій у викладанні ВТД. Це дозволяє зробити висновок про доцільність їх впровадження як у теорію, так і в практику освітнього процесу.

Подальші дослідження доцільно присвятити розробленню та застосуванню таких напрямів, як: мультимедійні віртуальні тренажери, моделювання навчальних ігор, автоматизована оцінка знань та інформаційно-дистанційнотренажерні системи.

військово-технічних дисциплін. Військова освіта Збірник наукових праць. НУОУ. 2013. №2 (28). С. 61-67. 5. Джеф Раскин Интерфейс: новые направления в проектировании компьютерных систем. 2010. URL: http://www.e-reading. club/book.php?book=89632. 6. Дерев'янчук А.Й. Сиротенко С.Г. Інформаційні технології інтенсифікації підвищення якості комп'ютеризованого навчання. Військова освіта: Збірник наукових праць. НУОУ. 2017. №1(35). С. 60-68. 7. Дерев'янчук А.Й., Чопа Д.А., Дегтярьов В.В., Семенов Ф.Д. Кейс-метод як форма інтерактивного навчання 3 військово-технічних дисциплін при підготовці фахівців РВ і А. Сучасні інформаційні технології у сфері безпеки та оборони. НУОУ. 2019. №1(34).

\title{
ИНФОРМАЦИОННЫЕ ТЕХНОЛОГИИ КАК ТЕХНИЧЕСКАЯ ОСНОВА РОЗВИТИЯ СОВРЕМЕННЫХ МЕТОДОВ ПРЕПОДАВАНИЯ ВОЕННО-ТЕХНИЧЕСКИХ ДИСЦИПЛИН
}

\author{
Дмитрий Анатольевич Чопа (кандидат технических наук, с.н.с.) ${ }^{1}$ \\ Анатолий Йосипович Деревьянчук (кандидат технических наук, профессор) $)^{2}$ \\ Владислав Валерьевич Дегтярьов ${ }^{2}$ \\ ${ }^{1}$ Национальный университет обороны Украины имени Ивана Черняховского, Киев, Украина \\ ${ }^{2}$ Сумськой государственный университет, Суммы, Украина
}

Современные условия применения Вооруженных Сил Украины определяют новые требования к организации обучения и подготовки военных специалистов. Сущеествует настоятельная необходимость в разработке новых технологий обучения, повышении уровня усвоения учебного материала и совершенствовании способов контроля его усвоения. Поэтому в статье на основе опыта кафедры 
военной подготовки Сумского государственного университета приводятся основные инновачионнье направления применения информачионных технологий в подготовке военных специалистов (на примере специалистов РВ и A), а именно, создание мультимедийных учебных комплексов по артиллерийской тематике, создание компьютерных обучающих систем, внедрение информационных и кейс - технологий в систему подготовки военных специиалистов, разработка мультимедийных виртуальных тренажеров (симуляторов), моделирование учебных игр, разработка системы автоматизированной оценки знаний и разработки информационно-дистаничионно-тренажерньй системь обучения. Авторы начинают собственный подход к конщепции применения современных методов преподавания военно-технических дисциплин с иелью дальнейтего их обсуждения, развития и внедрения в образовательньй прочесс вуза. В данной статье рассмотрено только часть основных инновачионных направлений применения информационных технологий. Остальные направления будут проанализированы и представлень в следующих публикациях.

Ключевые слова: информационные технологии; мультимедийные артиллерийские комплексы; кейс-метод; компьютерные обучающче системы; концепичи.

\title{
INFORMATION TECHNOLOGIES AS A TECHNICAL BASIS FOR THE DEVELOPMENT OF MODERN METHODS OF TEACHING MILITARY-TECHNICAL SUBJECTS
}

\author{
Dmitro Chopa (Candidate of technical sciences, Senior Research Fellow) ${ }^{1}$ \\ Anatolii Derevianchuk (Candidate of technical sciences, professor) ${ }^{2}$ \\ Vladyslav Dehtiarov ${ }^{2}$ \\ ${ }^{1}$ National Defence University of Ukraine named after Ivan Cherniakhovsky, Kyiv, Ukraine \\ ${ }^{2}$ Sumy State University, Sumy, Ukraine
}

Modern conditions for the use of the Armed Forces of Ukraine define new requirements for the organization of education and training of military specialists. There is an urgent need to develop new learning technologies, increase the level of learning material and improve ways to control its learning. Therefore, based on the experience of the Department of Military Training of Sumy State University, the article presents the main innovative areas of information technology in the training of military specialists (for example, artillery specialists), namely, the creation of multimedia artillery training complexes, the creation of computer-based training systems, the introduction of information and case technologies in the system of training military specialists, development of multimedia virtual simulators, modeling of educational games, the development of an automated knowledge assessment system and the development of information and distance learning equipment. The authors begin their own approach to the concept of applying modern methods of teaching military-technical disciplines with the aim of further discussing them, developing and introducing into the educational process of the university. This article covers only a part of the main innovative areas of information technology. The remaining directions will be analyzed and presented in the following publications.

Key words: information technologies; multimedia artillery complexes; case-method; computer training systems; concepts.

\section{References}

1. Kolganova A. Metod case-study kak sovremennaia pedahohycheskykh tekhnolohyia $\mathrm{v}$ obrazovanyy vzroslukh [The case-study method as a modern educational technology in adult education.]. URL: http://www.docplayer.ru /31560686 - Metod - case - study - kak - sovremennaya anii-vzroslyh-kolganova-alla-ivanovna-zav-sektorom-gcrdo. html. 2. Velichko G. (2002). Kompiuterni tekhnolohii navchannia [Computer technology training] Suchasni informatsiini tekhnolohii ta innovatsiini metodyky navchannia $\mathrm{v}$ pidhotovtsi fakhivtsiv: metodolohiia, teoriia, dosvid, problemy. Zb. nauk. pr. U 2-kh chast. Ch.2. / Za red. I.A. Ziaziuna (holova) ta in. Kyiv.Vinnytsia: DOV Vinnytsia. 3. Derevyanchuk A., Chopa D. (2012). Pidkhid do stvorennia prohramnykh zasobiv dlia vyvchennia viiskovo-tekhnichnykh dystsyplin [Approach to the creation of software for the study of military-technical disciplines]. Suchasni informatsiini tekhnolohii $\mathrm{v}$ sferi bezpeky ta oborony. NUOU. №1(13). 4. Derevyanchuk A., Moskalenko D., Dyakov A. (2012) Pidkhid do stvorennia prohramnykh zasobiv dlia vyvchennia viiskovo- tekhnichnykh dystsyplin [The use of information technology in the study of military-technical disciplines]. Suchasni informatsiini tekhnolohii v sferi bezpeky ta oborony. NUOU. №1(13). 5. Raskin J. (2010). Ynterfeis: novыe napravlenyia v proektyrovanyy kompiuternыkh system [Interface: new directions in the design of computer systems.]. URL:http://www.e-reading. club/book.php? book=89632. 6. Derevyanchuk A., Sirotenko S. (2017). Informatsiini tekhnolohii intensyfikatsii pidvyshchennia yakosti kompiuteryzovanoho navchannia [Information technologies of intensification of the improvement of the quality of computerized training]. Viiskova osvita: Zbirnyk naukovykh prats. NUOU. №1(35). S. 60-68. 8. Derevyanchuk A., Chopa D., Dehtiarov V., Semenov D. (2019). Keis-metod yak forma interaktyvnoho navchannia $\mathrm{z}$ viiskovotekhnichnykh dystsyplin pry pidhotovtsi fakhivtsiv RV i A [Case-method as a form of interactive training on militarytechnical disciplines in preparation of artilery specialists]. Suchasni informatsiini tekhnolohii u sferi bezpeky ta oborony. NUOU. №1(34). 